\title{
AN EXPERIMENTAL STUDY ON THE BEHAVIOUR OF MARINE CLAY TREATED WITH LIME AND COCONUT COIR FIBRE
}

\author{
R.N.V.S.R. Ravi Kiran \\ Postgraduate student, \\ Department of Civil Engineering \\ JNTUK Kakinada, A.P., India,
}

\begin{abstract}
India is a country with a coastal line of $7516.6 \mathrm{~km}$. This coastal region mostly consists of marine clay deposits. Use of locally available materials and soil will be economical for road construction. But in coastal region using marine clays (locally available soils) as sub grade will not yield desirable results due to its poor engineering properties. Replacing soil may not be cost effective. In this experimental study, under controlled conditions through laboratory tests, the effect of Coconut Coir Fibre and Lime as admixtures in stabilizing marine clay has been studied.
\end{abstract}

Keywords-Marine Clay, Lime, Coconut Coir Fibre, MDD, OMC, $C B R$

\section{INTRODUCTION}

In the construction of pavements, sub grade plays a pivotal role. Sub grade performance will affect the life span of the pavement. An appropriate soil has to be selected which can be used as sub grade. Poor performance of sub grade leads to high construction costs. To resolve this problem, different methods have been developed to minimize the variability in sub grade characteristics. Marine clay is one of the problematic soils which can be found on coastal region. Marine clays are microcrystalline in nature and it has clay minerals like Illite, Chlorite and Kaolinite. Marine clays tend to become stiff when dried but becomes soft when wetted. High shrinkage and low shear strength are the properties of marine clay. Due to its poor properties marine clay has to be pre-treated to be used as a sub grade in high ways. In improving soft soil generally replacement of soft soil with good stronger material will be used. Replacement of soil increases cost of the project. So to avert this problem there are different methods to improve soft soil in one of which chemical stabilization is considered as economical. In the present study, Coconut Coir Fibre and Lime are added to marine clay to evaluate its performances through laboratory tests such as Proctor Compaction test and California Bearing Ratio test.

\author{
Dr. K. Purnanandam \\ Professor \\ Department of Civil Engineering \\ JNTUK Kakinada, A.P., India,
}

\section{REVIEW OF LITERATURE}

Koteswara Rao D. and Prasada Raju G.V.R. (2011) conducted laboratory studies on the properties of stabilized Marine clay from Kakinada sea coast. B.B.K. Huat et al. (2014) studied the effect of lime and coir fibre on marine clay. There was a reduction in plasticity, moisture content and swell. The soil became ductile and cohesion increased among the soil particles.

\section{OBJECTIVES OF STUDY}

The objectives of the present experimental study are as follows

- To determine the properties of untreated marine clay.

- To determine the improvement in properties of marine clay after treating it with Coconut Coir Fibre and Lime.

- To improve the soil by using locally available, cheap and biodegradable materials.

\section{MATERIALS USED}

\section{A. Marine Clay}

Marine clay sample was collected from a dredging site, where dredging was carried out at a depth of $2-4 \mathrm{~m}$ below the Sea water level near Kakinada Sea Port Ltd. The collected samples were black in colour. The hydrometer analysis conducted on marine clay shows $58 \%$ of clay content and $28 \%$ of silt content.

TABLE 1: GEOTECHNICAL PROPERTIES OF THE UNTREATED MARINE CLAY

\begin{tabular}{|c|c|c|c|}
\hline S.No. & \multicolumn{2}{|c|}{ Properties } & $\begin{array}{c}\text { Marine } \\
\text { clay }\end{array}$ \\
\hline \multirow{3}{*}{1} & \multirow{2}{*}{ Soil classification } & Gravel (\%) & 0 \\
\cline { 3 - 4 } & & Sand (\%) & 14 \\
\cline { 3 - 4 } & & Silt (\%) & 28 \\
\cline { 3 - 4 } & & Clay (\%) & 58 \\
\hline
\end{tabular}




\begin{tabular}{|c|c|c|}
\hline 2 & Liquid limit ( \% ) & 77.00 \\
\hline 3 & Plastic limit (\%) & 27.5 \\
\hline 4 & Plasticity index (\%) & 49.5 \\
\hline 5 & Soil classification & $\mathrm{CH}$ \\
\hline 6 & Specific Gravity & 2.42 \\
\hline 7 & Differential free swell ( \% ) & 90 \\
\hline 8 & MDD ( g/cc ) & 1.362 \\
\hline 9 & OMC (\%) & 29.2 \\
\hline 10 & CBR (\%) & 1.568 \\
\hline
\end{tabular}

\section{B. Coconut Coir Fibre}

Coconut Coir Fibre is a natural biodegradable material abundantly available in some parts of South and Coastal regions of India. It is locally available with practically little cost. Coir used in this experimentation is brought from Amalapuram, East Godavari district, Andhra Pradesh.

TABLE 2: PROPERTIES OF COCONUT COIR FIBRE

\begin{tabular}{|c|c|c|}
\hline S.No. & Property & Value \\
\hline 1 & Length ( inches ) & 6.80 \\
\hline 2 & Density ( g/cc ) & 1.40 \\
\hline 3 & Breaking Elongation ( \% ) & 30 \\
\hline 4 & Diameter ( mm ) & $0.1-1.5$ \\
\hline 5 & Lignin ( \% ) & 45.84 \\
\hline 6 & Cellulose (\% ) & 43.44 \\
\hline 7 & Hemi-Cellulose ( \% ) & 0.25 \\
\hline 8 & Pectin (\% ) & 3.00 \\
\hline
\end{tabular}

( Courtesy: www.coirinstitute.com )

\section{Lime}

Calcium Hydroxide i.e. Hydrated Lime is used in this experimental study and it is procured from a local vendor

\section{LABORATORY STUDIES}

The laboratory studies were carried out on the samples of Marine clay, Marine clay treated with optimum of Coconut Coir Fibre and Marine Clay treated with Coconut Coir Fibre and Lime

\section{Liquid Limit}

Liquid Limit test was performed on Marine clay, Marine clay $+0.5 \%$ Coconut Coir Fibre, Marine clay $+0.5 \%$ Coconut Coir Fibre $+6 \%$ Lime using Casagrande's Liquid Limit apparatus as per the procedure laid down in IS: 2720 part 4 (1970).

\section{Plastic Limit}

Plastic Limit test was performed on Marine Clay, Marine clay $+0.5 \%$ Coconut Coir Fibre, Marine clay $+0.5 \%$ Coconut Coir Fibre $+6 \%$ Lime as per the specifications laid down in IS: 2720 part 4 (1970).

\section{Modified Proctor Compaction Test}

The optimum moisture content and maximum dry density have an important role in changing the strength properties of clay. Preparation of soil sample for Proctor's compaction test was done as per IS: 2720 part-6 (1974).

\section{Specific Gravity Test}

Specific gravity is the ratio of the mass of unit volume of soil at a stated temperature to the mass of the same volume of gas free distilled water at a stated temperature. The specific gravity of a soil is used in the phase relationship of air, water, and solids in a given volume of the soil. Specific gravity test was carried out by Pycnometer as per IS 2720 Part 3 (1980).

\section{California Bearing Ratio Test}

The California bearing ratio tests are conducted on Marine Clay, Marine Clay treated with CCF, and Marine clay with optimum of CCF and percentage variation of Lime mixtures as per IS 2720 part 16 (1979). The test was conducted under a constant strain rate of $1.25 \mathrm{~mm} / \mathrm{min}$. The proving ring reading is noted for 50 divisions, and loading was continued until 3 (or) more readings are decreasing (or) constant. The test was conducted at Optimum moisture content. The samples were tested in soaked condition. The tests were conducted at time interval of curing for 4 days

\section{RESULTS AND DISCUSSIONS}

\section{Compaction test results when soil is treated with various} percentage of $\mathrm{CCF}$

Coconut Coir Fibre is added to Marine Clay in different percentages varying from $0.25 \%$ to $1 \%$ to improve its properties. Table 3 and figures $1 \& 2$ present the OMC and MDD values of untreated marine clay and also marine clay treated with various percentages of Coconut Coir Fibre.

TABLE 3: OMC AND MDD VALUES OF UNTREATED AND TREATED MARINE CLAY

\begin{tabular}{|l|l|l|l|}
\hline S.No. & Mix & OMC ( \% ) & MDD ( g/cc ) \\
\hline 1 & Untreated Soil & 29.2 & 1.362 \\
\hline 2 & $\begin{array}{l}\text { Marine Clay + } \\
0.25 \% \text { CCF }\end{array}$ & 30.5 & 1.32 \\
\hline 3 & $\begin{array}{l}\text { Marine Clay + } \\
0.5 \% \text { CCF }\end{array}$ & 31.25 & 1.31 \\
\hline 4 & $\begin{array}{l}\text { Marine Clay + } \\
0.75 \% \text { CCF }\end{array}$ & 34.0 & 1.29 \\
\hline 5 & $\begin{array}{l}\text { Marine Clay + } \\
1 \% \text { CCF }\end{array}$ & 1.285 \\
\hline
\end{tabular}




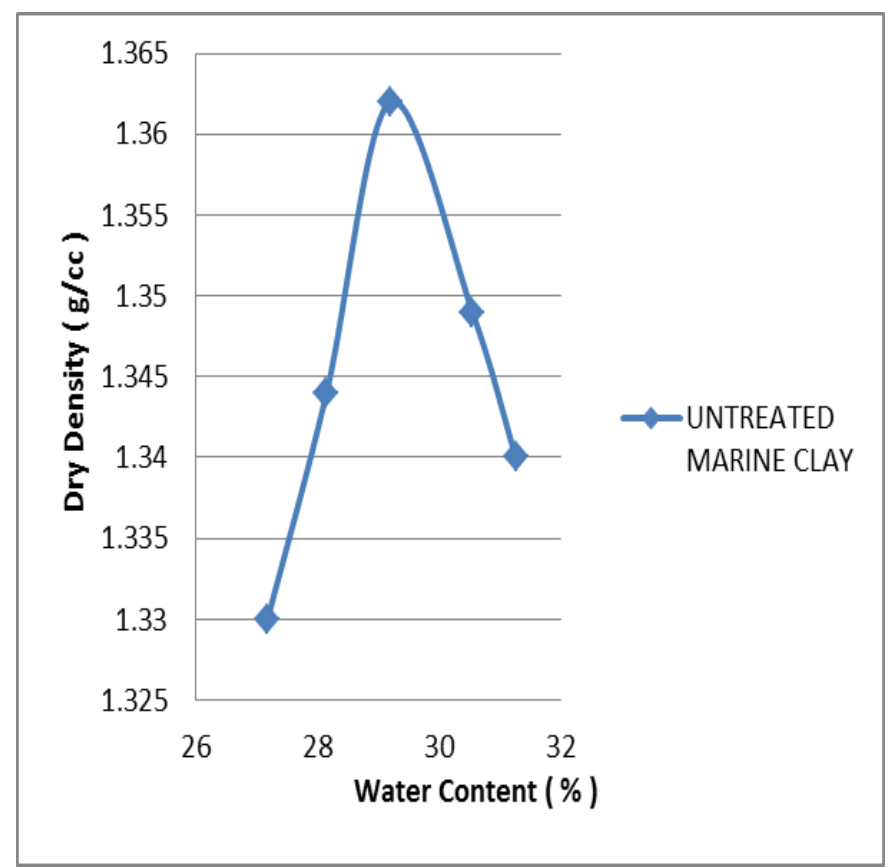

Fig.1 OMC and MDD values of untreated Marine Clay

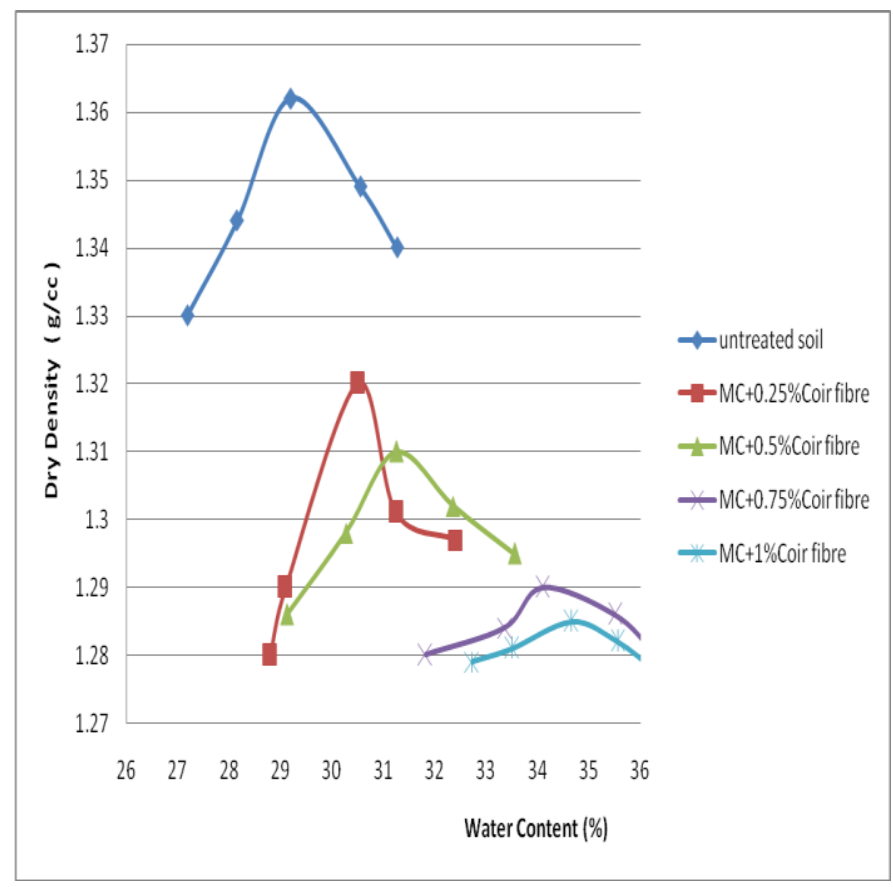

Fig.2 OMC and MDD values of Marine Clay treated with various percentages of $\mathrm{CCF}$

2. CBR test values when treated with various percentages of $\mathbf{C C F}$

CBR values of various mixes of marine clay and coconut coir fibre compacted at $\mathrm{OMC}$ obtained from compaction are determined. The soaked CBR after immersing in water for four days, that is when full saturation is likely to occur, is also determined The CBR test was carried out as per the IS code 2720 part 16, 1987. Table 4 and fig. $3 \& 4$ present the CBR values of untreated marine clay and also marine clay treated with various percentages of Coconut Coir Fibre

TABLE 4: CBR VALUES OF UNTREATED AND TREATED MARINE CLAY WITH VARIOUS PERCENTAGES OF CCF

\begin{tabular}{|l|l|l|}
\hline S.No. & Mix & CBR (\%) \\
\hline 1 & Marine Clay + 0\%CCF & 1.568 \\
\hline 2 & Marine Clay + 0.25\%CCF & 2.010 \\
\hline 3 & Marine Clay + 0.5\%CCF & 3.585 \\
\hline 4 & Marine Clay + 0.75\%CCF & 2.464 \\
\hline 5 & Marine Clay + 1\%CCF & 2.240 \\
\hline
\end{tabular}

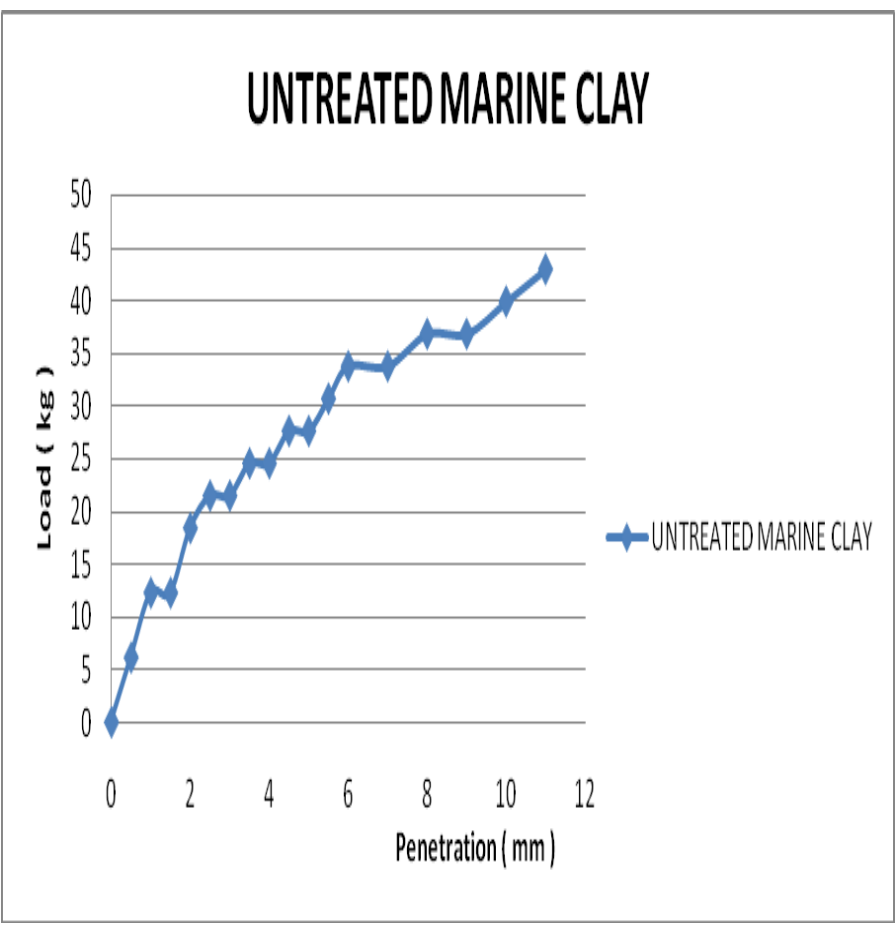

Fig.3 CBR graph of untreated Marine Clay 


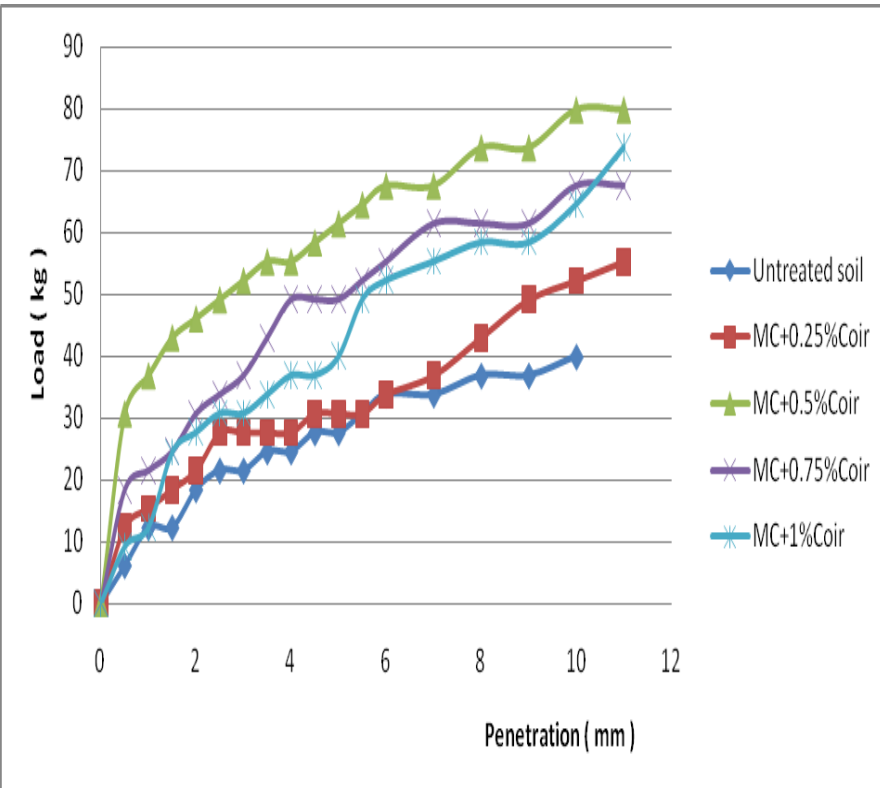

Fig.4 CBR graphs of treated Marine Clay with various percentage of $\mathrm{CCF}$

3. Compaction test results when soil is treated with $0.5 \%$ Coconut Coir Fibre and various percentages of Lime

Table 5 and figure 5 present the variation of OMC and MDD values of untreated marine clay and also marine clay treated with $0.5 \%$ coconut coir fibre and various percentages of Lime TABLE 5: OMC AND MDD VALUES OF MARINE CLAY+0.5\%COCONUT COIR FIBRE TREATED WITH VARIOUS PERCENTAGES OF LIME

\begin{tabular}{|l|l|l|l|}
\hline S.No. & $\begin{array}{l}\text { Marine Clay+0.5\% } \\
\text { CCF treated with } \\
\text { various percentage } \\
\text { of Lime }\end{array}$ & OMC (\%) & MDD(g/cc) \\
\hline 1 & 4 & 30.75 & 1.326 \\
\hline 2 & 6 & 32.5 & 1.320 \\
\hline 3 & 8 & 34.8 & 1.280 \\
\hline
\end{tabular}

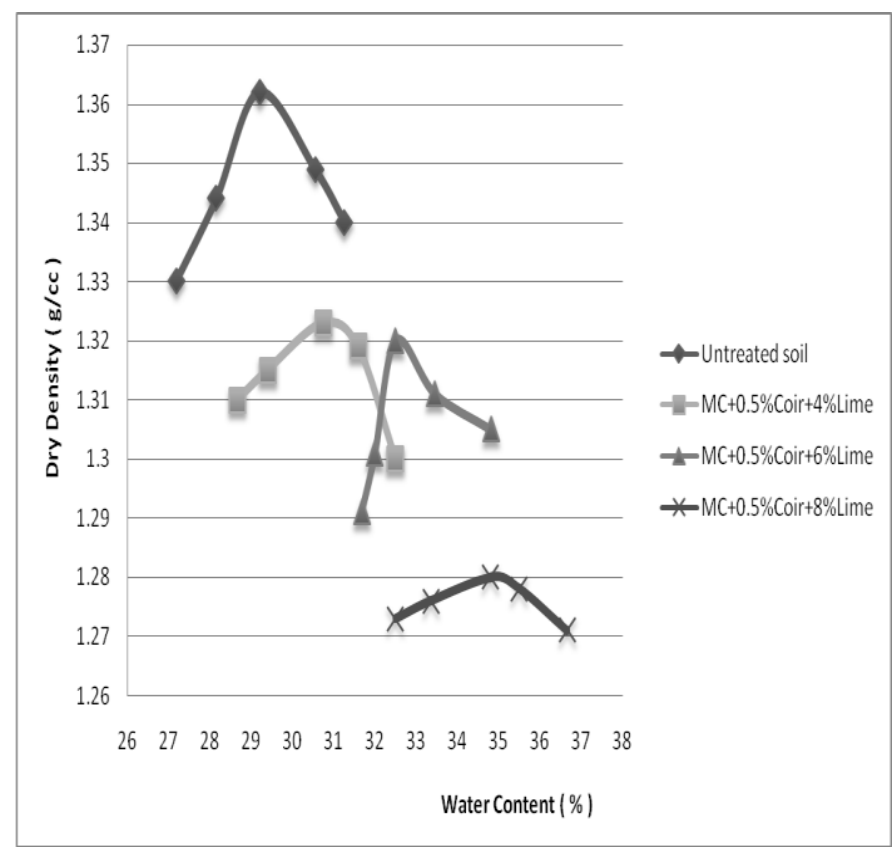

Fig.5 Marine clay+0.5\% CCF treated with various percentage of Lime

4. CBR test results when soil is treated with $0.5 \%$ Coconut Coir Fibre and various percentages of Lime

Table 6 and figure 6 present the variation of CBR values of untreated Marine Clay and also Marine Clay treated with $0.5 \%$ Coconut Coir Fibre and various percentages of Lime

TABLE 6: MARINE CLAY+0.5\% CCF TREATED WITH VARIOUS PERCENTAGE OF LIME

\begin{tabular}{|l|l|l|}
\hline S.No. & $\begin{array}{l}\text { Marine Clay+0.5\% CCF } \\
\text { treated } \\
\text { with various } \\
\text { percentage of Lime }\end{array}$ & \\
\hline 1 & 4 & 6.050 \\
\hline 2 & 6 & 8.291 \\
\hline 3 & 8 & 8.515 \\
\hline
\end{tabular}




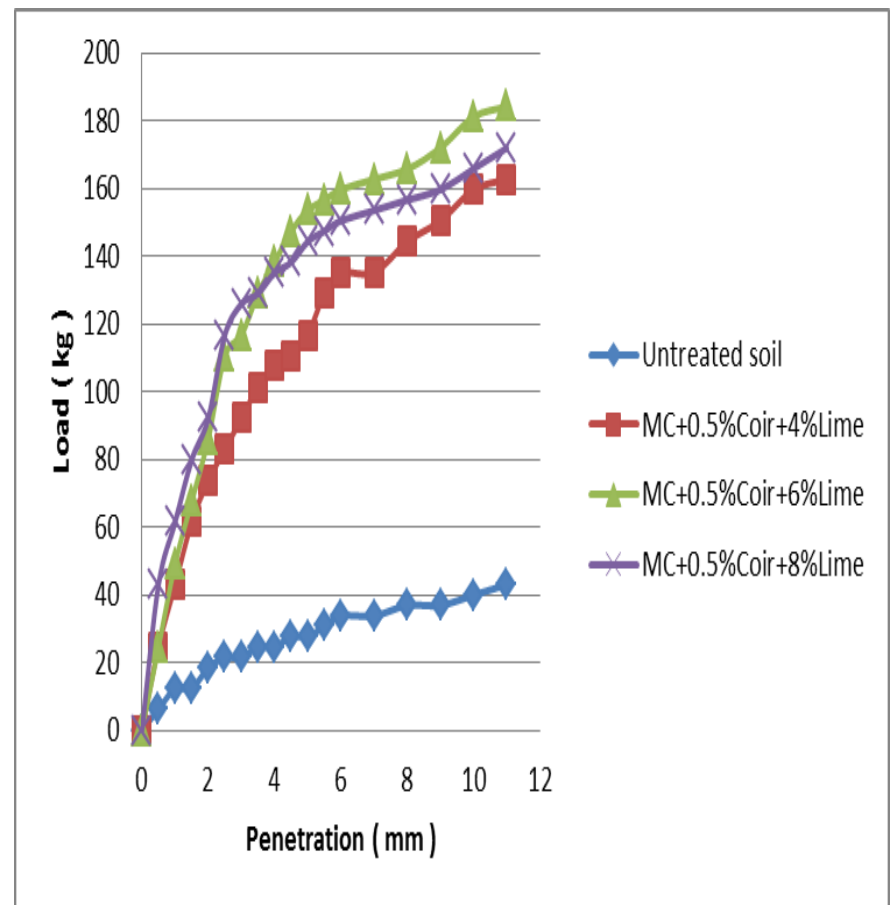

Fig.6 Marine Clay+0.5\% CCF treated with various percentage of Lime

Laboratory tests results of Liquid limit, Plastic limit, Plasticity Index, Compaction and CBR were conducted on the marine clay treated with the optimum percentage of CCF and Lime are as follows:

TABLE 7: LABORATORY TEST RESULTS OF THE UNTREATED AND TREATED MARINE CLAY

\begin{tabular}{|c|c|c|c|c|}
\hline S.No. & Properties & $\begin{array}{l}\text { Marine } \\
\text { clay }\end{array}$ & $\begin{array}{l}\mathrm{MC}+ \\
0.5 \% \mathrm{CCF}\end{array}$ & $\begin{array}{l}\text { MC+0.5\% } \\
\text { CCF+ 6\% } \\
\text { Lime }\end{array}$ \\
\hline 1 & $\begin{array}{l}\text { Liquid } \\
\text { limit }(\%)\end{array}$ & 77.00 & 68.5 & 61 \\
\hline 2 & $\begin{array}{l}\text { Plastic } \\
\text { limit (\%) }\end{array}$ & 26.5 & 29.0 & 31 \\
\hline 3 & $\begin{array}{l}\text { Plasticity } \\
\text { index }(\%)\end{array}$ & 49.5 & 39.5 & 30 \\
\hline 4 & $\begin{array}{l}\text { Soil } \\
\text { Classificati } \\
\text { on }\end{array}$ & $\mathrm{CH}$ & $\mathrm{CH}$ & $\mathrm{CH}$ \\
\hline 6 & $\begin{array}{l}\operatorname{MDD}(g / c c \\
\text { ) }\end{array}$ & 1.362 & 1.31 & 1.32 \\
\hline 7 & OMC (\%) & 29.2 & 31.5 & 32.5 \\
\hline 8 & CBR (\%) & 1.568 & 3.585 & 8.291 \\
\hline
\end{tabular}

\section{CONCLUSIONS}

1. It is observed that the liquid limit of the marine clay soil has been decreased by $11.03 \%$ on addition of $0.5 \%$ coconut coir fibre and it has been further decreased by $20.77 \%$ when $6 \%$ Lime is added.

2. It is observed that the plastic limit of the marine clay soil has been increased by $9.43 \%$ on addition of $0.5 \%$ coconut coir fibre and it has been further increased by $16.98 \%$ when $6 \%$ Lime is added.

3. It is observed that the plasticity index of the marine clay soil has been decreased by $21.78 \%$ on addition of $0.5 \%$ coconut coir fibre and it has been further decreased by $40.59 \%$ when $6 \%$ Lime is added.

4. It is observed that the OMC of the marine clay soil has been increased by $7.87 \%$ on addition of $0.5 \%$ coconut coir fibre and it has been further increased by $11.30 \%$ when $6 \%$ Lime is added.

5. It is observed that M.D.D of the marine clay has been decreased by $3.81 \%$ on addition of $0.5 \%$ coconut coir fibre and it has been further increased by $0.76 \%$ when $6 \%$ Lime is added.

6. It is observed that the soaked C.B.R. value of the marine clay has been improved by $428.76 \%$ on addition of $0.5 \%$ coconut coir fibre and $6 \%$ Lime compared to the untreated soil.

\section{REFERENCES}

1) Koteswara Rao, D \& Prasada Raju, G.V.R. \& , Sowjanya \& , Ch \& Purnachandra Rao, J. (2011). Laboratory Studies on the Properties of Stabilized Marine Clay from Kakinada Sea Coast, India. International Journal of Engineering Science and Technology. 3.

2) Koteswara Rao D, Pranav P.R.T., Venkatesh Ganja ( 2012 )"A Laboratory Study on the Lime and Sawdust Treated Marine Clay Subgrade Flexible Pavement Under Cyclic Pressure', International Journal of Engineering and Innovative Technology (IJEIT) Volume 2, Issue 4, October 2012

3) Koteswara Rao D, M.Anusha, P.R.T. Pranav, G.Venkatesh ' A Laboratory Study on the Stabilization of Marine Clay Using Sawdust and Lime', [IJESAT] International Journal of Engineering Science \& Advanced Technology Volume-2, Issue-4, 851 - 862

4) Anggraini, Vivi \& Huat, Bujang \& ASADI, Afshin \& Nahazanan, Haslinda. (2014). ''Effect of coir fibre and lime on geotechnical properties of marine clay soil.",

5) Basack, Sudip \& Purkayastha, R.(2009). Engineering properties of marine clays from the eastern coast of India. 1.

6) Teresa Sunny and Annie Joy (2016)," Study on the Effects of Marine Clay Stabilized with Banana Fibre", 
International Journal of Scientific Engineering and Research (IJSER), Volume- 4 Issue 3, pp.96-98.

7) Dayakar Babu ,R, K. V. S. Raja Praveen, K.VijayTeja, , K. V. N. S. Raviteja (2013)"'Strength Behaviour of Marine Clay Stabilized with Lime - Quarry Rock Dust and Waste Plastics" Proceeding of Conference Paper June 2013

8) KoteswaraRao.D, G.V.V. Rameswara Rao, P.R.T. Pranav (2012)“A Laboratory Study on the Affect of Rice Husk Ash \& Lime on the Properties of Marine Clay" International Journal of Engineering and Innovative Technology (IJEIT), Volume 2, Issue 1,PP 345-353.

9) Rajasekaran, G and Narasimha Rao, S (2002), Compressibility Behaviour of Lime Treated Marine Clay, Journal of Ocean Engineering, volume-29, pp. 545559.

10) KVNS, Raviteja \& Dayakar, Teja. (2013). Strength Behaviour Of Marine Clay Stabilized With Lime-Quarry Rock Dust \& Waste Plastics. AGE- Indian Geotechnical Society, Surat Chapter.

11) IS: 2720 part- 4 (1975): Grain size analysis

12) IS: 2720 part- 5 (1970): Determination of Liquid Limit and Plastic Limit

13) IS: 2720 part- 6 (1974): Determination of Dry density and Optimum Moisture Content

14) IS: 2720 Part-16 (1979): Determination of California Bearing Ratio 